原著：

\title{
中高年のいちご栽培従事者における 身体的疲労部位と関連作業要因
}

\author{
百 瀬 義 ${ }^{*}$, 末永隆次郎 ${ }^{2 *}$, 畧
}

博 ${ }^{*}$

新しい栽培方法による労働態樣の変化, 並びにいちご栽培従事者の高齢化が進行してい る。光れに伴い, 中高年のいちこ栽培従事者に対する新たな疲労対策を講じる必要性が高 くなった。本研究では, いちご栽培作業による身体的疲労部位を明らかにし, 改善すべき 作業要因を見出すことを目的とした自記式質問紙調査を実施した。解析対象者は40〜69歳 までのいちご栽培従事者1 113名（男性681名，女性432名）とした。身体的疲労部位の訴 えでは, 腰が最も多かった（男性74 .0\%，女性73 8\%)。次いで，肩（男性49.6\%，女性 $604 \%$ ), 目 (男性45 2\%, 女性50 .9\%) の順だった。これらの疲労部位と作業要因との 関連を検討するため, ロジスティック回帰分析法を用いた。年齢，作業時間，及び睡眠時 間で調整後のオッズ比 (OR) と95\%信頼区間 (CI) を求めた結果, 腰の疲労と最も強い 有意な関連を示した作業は, 男性では農薬散布 (OR2 .0；CI1 4 2 8) だったが, 女性 では関連がみられなかった。肩の疲労との関連では, 男性は葉かき作業 (OR1 5; CI1 1 〜2 2), 女性は農薬散布 (OR1 .6 ; CI1 1〜2 4) が最も強かった。目の疲労との関連で は，男性では選別・調整作業 (OR2 .7 ; CI : 1 .9 3 8) ，女性は収穫作業 (OR3 2 ； CI2 .0 ～5 1) が強かった。主な身体的疲労部位は男女同樣だったが, 強い関連を示す作業要因 は男女で異なり，性差を考慮した疲労対策が必要と考えられた。

(1)いちご (2)疲労 (3)オッズ比

$$
\text { I. 緒言 }
$$

いちごは, 育苗と実取り栽培との双方を管理 するため, 年間を通しての栽培作物である。九 州農政局福岡統計情報センターの報告による $と^{1)}$, 福岡県下における平成13年度いちご作付 面積は557haで, 収穫量は22,800t, 出荷量が $21,700 \mathrm{t}$ と報告されており，全国でトップを争 う作物である。しかし，いちこ栽培従事者の高 齢化と過重労働の影響等から ${ }^{2)}$, 光の伸びは停 滞傾向にあり, いちご生産振興のためには労力

* = 814-0180 福岡市城南区七隈7-45-1

福岡大学医学部衛生学教室

${ }^{2 *}$ 久留米大学医学部環境医学教室

(受付 : 2005年 1 月14日)
削減が重要課題となっている。

九州地域における促成いちごの育苗ではポッ 卜育苗が主体であるが，育苗期間が長く，毎日 の管理と苗の運搬など, 栽培従事者に長時間労 働と重労働を強いている面がある。主力品種と して栽培されてきた「とよのか」は，早生で高 収量，しかも香気性が高く食味に優れている が, 果実の大きさや形状から, 収穫, 選別・調 整，パック詰めの出荷作業に多大な労力を必要 とした。光こで，いちご栽培の省力化・軽作業 化を目的とした新しい育苗法の開発への取り組 みや高設栽培技術の確立，あるいは前進出荷を 目的とした低温処理育苗法の開発等が，現在進 められている3 ${ }^{3 \sim 5)}$

従来の土耕型栽培の労働負担軽減対策として 
は，作業台車等による作業姿勢の改善か試みら れているが，しゃがみ姿勢を改善しても体幹部 をねじっての捻り姿勢が多くなるなど, 異なる 不良作業姿勢の問題が表れている6)。また，照 明や作業台の工夫等の環境面での改善もなされ ている7)。一方で, 最近注目されている高設栽 培は, 定植, 葉かき, 収穫作業の省力化や中 腰・しゃがみ姿勢が少なくなるメリットがある 反面, 高設台への直接定植と育苗の過重労働や 立ちつぱなしの姿勢による身体的負担の増加と いうデメリットがある。いちごの産地間競争は 激しく, 兴の特徵は新品種開発と出荷時期をず らす産地の差別化がポイントとなり，市場での 地位を維持・拡大する競争になってきている8 。

このような近年のいちごの品種改良や新しい 栽培方法などの労働態樣の変化や競争の激化， 並びにいちご栽培従事者の高齢化の進行を考慮 すると, 中高年のいちこ栽培従事者に対する労 働衛生上の新しい疲労対策を講じる必要性が高 い。身体的疲労対策に当たっては, 作業内容に 加え，作業時間の長さや睡眠時間のとり方も疲 労を増悪させる要因として重視する必要があ る。本報告では中高年齢者のいちご栽培作業に 焦点を当て, 主な身体的疲労部位を明らかに し, 兴の疲労がどのような作業要因と関連がみ られるかを検討した。

$$
\text { II. 研 究方 法 }
$$

\section{1. 研究対象}

福岡県 JA 全農ふくれん（いちご部会）会員 のいちご栽培従事者2 133名。

\section{2 . 調査方法}

いちご収穫が始まる前にあたる2002年11月， いちこ部会を通じて記名式質問紙を配布した。 夫婦あるいは家族でいちこ栽培に従事している 場合を考慮し，1世帯に2 部ずつ配布・回収し た。解析データは, 年齢, 性別, 作業内容の実 施割合 [(1)溝上げ (溝上げ機で畧を作る)，(2) 葉かき (古くなった葉を早めに取り去る)，(3) ランナー取り (伸びたつるに栄養が行かないよ うに切り取る)，(4)農薬散布，(5)ジベレリン処 理 (花芽が見えてくる時にジベレリンを与えて
果房を伸ばす方法)，(6)マルチング作業（畧を 黑いポリフィルムで覆い, , いちごの株の真上に 小さな穴を開け，葉を傷めないように引き出す ことにより, 地温の確保, 杂隹草発生の防止, い ちごの実と土が直接触れることなく，泥が付い たり腐ったりすることを防ぐ），(7サイドのビ ニール張り作業，8天井ビニールを張るための 下準備，(9)八ウスのビニール張り，(10)収穫作 業, 价選別・調整作業]，いちご栽培作業によ る身体的疲労部位 (目, 首, 肩, 腕, 手指, 背 中, 腰, 大腿部, 下腿部, 足首, 足底部, 足, 足指の14か所)，いちご栽培にかかわる作業時 間，及び睡眠時間とした。

\section{3. 解析方法}

質問紙は1 ,622名から回収された。中高年齢 層 (40〜69歳) に焦点をあてるため，20〜39歳 158名と70〜85歳168名を除いた。さらに現病歴 で腰痛治療中の183名 (男性104名, 女性79名) は，医師の指示による作業内容の軽減等，解析 に影響があると考えられるため除いた。产の結 果, 解析対象は1 113名 (男性681名, 平均年齢

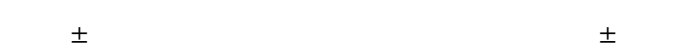
歳) とした。解析対象者の特徵を把握するた め, 年齢により 3 群 (10歳階級) に分け，身体 的疲労部位 ·作業内容 ·作業時間 - 睡眠時間を 比較した。対象者の年齢構成等の割合に関する 有意差検定には Mantel-Haentzel $\chi^{2}$ 検定を用 いた。平均値による有意差検定は, 分散分析法 を用いた。作業要因の身体的疲労部位への関与 の大きさを検討するため，身体的疲労部位の有 無を従属変数，いちご栽培の各作業内容を独立 変数としたロジスティック回帰分析を用いて， オッズ比と炎の95\%信頼区間を計算した。オッ ズ比は年齢，作業時間，及び睡眠時間で調整し た。有意水準は $5 \%$ の両側検定とし，計算は福 岡大学情報処理センター内高速演算サーバー上 の statistical analysis system (SAS) を用い て行なった。

$$
\text { III. 結果 }
$$

1. 身体的疲労部位の愁訴率 (表 1 )

最も多かった身体的疲労部位は, 腰 (男性 
表 1 . 性別・年齢階層別にみた身体的疲労部位の愁訴率 (\%)

\begin{tabular}{|c|c|c|c|c|c|c|c|}
\hline & & 性別 & 40歳代 & 50歳代 & 60歳代 & 全年齢 & $\mathrm{p}$-value \\
\hline \multirow[t]{2}{*}{ 人 数 } & & 男性 & 203 & 268 & 210 & 681 & \\
\hline & & 女性 & 124 & 171 & 137 & 432 & \\
\hline \multirow[t]{2}{*}{ 目 } & $(\%)$ & 男性 & 42.4 & 48.5 & 438 & 452 & \\
\hline & & 女性 & 452 & 532 & 533 & 50.9 & \\
\hline \multirow[t]{2}{*}{ 首 } & $(\%)$ & 男性 & 212 & 16.0 & 16.7 & 178 & \\
\hline & & 女性 & 218 & 24.0 & 20.4 & 222 & \\
\hline \multirow[t]{2}{*}{ 肩 } & $(\%)$ & 男性 & 542 & 51.5 & 42.9 & 49.6 & 0.02 \\
\hline & & 女性 & 605 & 608 & 59.9 & $60.4^{* * *}$ & \\
\hline \multirow[t]{2}{*}{ 腕 } & $(\%)$ & 男性 & 138 & 17.5 & 15.7 & 159 & \\
\hline & & 女性 & 19.4 & 20.5 & 27.7 & $22.4^{* *}$ & \\
\hline \multirow[t]{2}{*}{ 手指 } & $(\%)$ & 男性 & 79 & 101 & 8.6 & 9.0 & \\
\hline & & 女性 & 18.6 & 193 & 131 & $171^{* * *}$ & \\
\hline \multirow[t]{2}{*}{ 背中 } & $(\%)$ & 男性 & 17.7 & 14.6 & 152 & 15.7 & \\
\hline & & 女性 & 161 & 211 & 21.9 & 19.9 & \\
\hline \multirow[t]{2}{*}{ 腰 } & $(\%)$ & 男性 & 764 & 75.0 & 70.5 & 74.0 & \\
\hline & & 女性 & 75.0 & 72.5 & 74.5 & 738 & \\
\hline \multirow[t]{2}{*}{ 膝 } & $(\%)$ & 男性 & 153 & 258 & 22.4 & 21.6 & \\
\hline & & 女性 & 21.0 & 24.0 & 35.0 & 26.6 & 0.0094 \\
\hline \multirow[t]{2}{*}{ 大腿部 } & $(\%)$ & 男性 & 3.9 & 11.6 & 10.0 & 88 & 0.03 \\
\hline & & 女性 & 6.5 & 4.7 & 73 & 6.0 & \\
\hline \multirow[t]{2}{*}{ 下腿部 } & $(\%)$ & 男性 & 39 & 5.6 & 48 & 49 & \\
\hline & & 女性 & 5.7 & 6.4 & 102 & 7.4 & \\
\hline \multirow[t]{2}{*}{ 足首 } & $(\%)$ & 男性 & 5.4 & 3.0 & 5.7 & 4.6 & \\
\hline & & 女性 & 6.5 & 6.4 & 8.0 & 6.9 & \\
\hline \multirow[t]{2}{*}{ 足底部 } & $(\%)$ & 男性 & 6.4 & 75 & 6.7 & 6.9 & \\
\hline & & 女性 & 121 & 152 & 8.0 & $12.0^{* *}$ & \\
\hline \multirow[t]{2}{*}{ 足 } & $(\%)$ & 男性 & 168 & 153 & 16.7 & 162 & \\
\hline & & 女性 & 145 & 12.3 & 19.0 & 151 & \\
\hline \multirow[t]{2}{*}{ 足指 } & (\%) & 男性 & 25 & 3.0 & 3.3 & 29 & \\
\hline & & 女性 & 2.4 & 2.9 & 22 & 2.6 & \\
\hline
\end{tabular}

有意差検定 : Mantel-Haentzel $\chi^{2}$ 検定

性別有意差 : ${ }^{* * *} \mathrm{p}<0.001,{ }^{* *} \mathrm{p}<0.01$ 年齢階層別有意差 : p-value

$74.0 \%$, 女性73 8\%) だった。次いで, 肩 (男 性49.6\%, 女性60 .4\%, 男女差 $\mathrm{p}<0.001)$, 目 (男性45 2\%，女性50 .9\%) の順に多かった。 これら 3つの主な愁訴のうち，年齢階層別比較 で有意差を認めたのは肩 (男性のみ) で, 若い 年代ほど愁訴率が高かった $(\mathrm{p}<0.05)$ 。一方， 膝は, 上位 3 項目に比べて疲労の訴えは少な かった（男性21.6\%，女性26.6\%)。なお，女 性の膝の愁訴率では年齢階層で差がみられ，高 年齢層ほど疲労の訴えが多かった（40歳代
$21.0 \% ， 50$ 歳代24.0\%，60歳以上35 .0\%, p< $0.01)$ 。大腿部」の疲労では, 男性において年 齢階層に差を認め $(\mathrm{p}<0.05), 50$ 歳代と60歳 代で高率だった。

2. 作業実施率，作業時間および睡眠時間（表 2 )

作業内容の実施率を多い順にみると，ラン ナー取り（男性85 .0\%，女性90.7\%)，葉かき

(男性73.0\%，女性84 5\%)，収穫作業（男性 $68.4 \%$, 女性73 2\%)，選別・調整作業（男性 
表 2 . 性別・年齢階層別にみた作業実施率，作業時間および睡眠時間

\begin{tabular}{|c|c|c|c|c|c|c|}
\hline & 性別 & 40歳代 & 50歳代 & 60歳代 & 全年齢 & $p$-value \\
\hline \multirow[t]{2}{*}{ 人数 } & 男性 & 203 & 268 & 210 & 681 & \\
\hline & 女性 & 124 & 171 & 137 & 432 & \\
\hline \multirow[t]{2}{*}{ 溝上げ } & 男性 & 42.9 & 46.3 & 519 & $47.0^{* * *}$ & \\
\hline & 女性 & 38.7 & 31.0 & 40.9 & 363 & \\
\hline \multirow[t]{2}{*}{ 葉かき } & 男性 & 66.0 & 71.6 & 814 & 73.0 & 0.0004 \\
\hline & 女性 & 863 & 82.5 & 85.4 & $845^{* * *}$ & \\
\hline ランナー取り & 男性 & 76.9 & 881 & 891 & 85.0 & 0.0006 \\
\hline$(\%)$ & 女性 & 903 & 93.0 & 883 & $90.7^{* *}$ & \\
\hline \multirow[t]{2}{*}{ 農薬散布 } & 男性 & 69.5 & 698 & 662 & $68.6^{* * *}$ & \\
\hline & 女性 & 34.7 & 368 & 482 & 398 & 0.02 \\
\hline \multirow{2}{*}{$\begin{array}{r}\text { ジベレリン処理 } \\
(\%)\end{array}$} & 男性 & 54.7 & 545 & 61.0 & $565^{* * *}$ & \\
\hline & 女性 & 29.0 & 292 & 358 & 313 & \\
\hline \multirow{2}{*}{$\begin{array}{r}\begin{array}{r}\text { マルチング作業 } \\
(\%)\end{array} \\
\end{array}$} & 男性 & 438 & 45.9 & 562 & 48.5 & 0.012 \\
\hline & 女性 & 59.7 & 602 & 60.6 & $602^{* * *}$ & \\
\hline \multirow{2}{*}{$\begin{array}{l}\text { サイドのビニール } \\
\text { 張り作業 } \quad(\%)\end{array}$} & 男性 & 478 & 474 & 61.0 & 51.7 & 0.007 \\
\hline & 女性 & 48.4 & 48.5 & 59.9 & 521 & \\
\hline \multirow{2}{*}{$\begin{array}{l}\text { 天井ビニールを } \\
\text { 張る下準備 (\%) }\end{array}$} & 男性 & 42.9 & 433 & 519 & 458 & \\
\hline & 女性 & 47.6 & 515 & 53.3 & 50.9 & \\
\hline \multirow{2}{*}{$\begin{array}{l}\text { ハウスビニール } \\
\text { 張り作業 } \quad(\%)\end{array}$} & 男性 & 453 & 478 & 58.6 & 50.4 & 0.007 \\
\hline & 女性 & 56.5 & 57.9 & 63.5 & $593^{* *}$ & \\
\hline \multirow[t]{2}{*}{ 収穫 } & 男性 & 69.0 & 67.5 & 691 & 68.4 & \\
\hline & 女性 & 75.0 & 702 & 752 & 732 & \\
\hline \multirow[t]{2}{*}{ 選別・調整 (\%) } & 男性 & 631 & 642 & 62.9 & 634 & \\
\hline & 女性 & 702 & 71.4 & 693 & $704^{*}$ & \\
\hline \multirow{2}{*}{$\begin{array}{l}\text { 作業時間 } \\
\quad(\text { 時間/日) }\end{array}$} & 男性 & $8.7\left(\begin{array}{ll}0 & 1\end{array}\right)$ & $8.7\left(\begin{array}{ll}0 & 1\end{array}\right)$ & $82\left(\begin{array}{ll}0 & 1\end{array}\right)$ & $8.5\left(\begin{array}{ll}0 & 1)^{* * *}\end{array}\right.$ & 0.0012 \\
\hline & 女性 & $78\left(\begin{array}{ll}0 & 1\end{array}\right)$ & $8.0\left(\begin{array}{ll}0 & 1\end{array}\right)$ & $8.0\left(\begin{array}{ll}0 & 1\end{array}\right)$ & $7.9(01)$ & \\
\hline \multirow{2}{*}{ 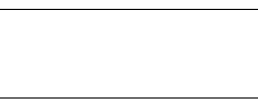 } & 男性 & $75\left(\begin{array}{ll}0 & 1\end{array}\right)$ & $7.7\left(\begin{array}{ll}0 & 1\end{array}\right)$ & 78 (0 1) & $7.6(0.04)^{* * *}$ & 0.0006 \\
\hline & 女性 & $65\left(\begin{array}{ll}0 & 1\end{array}\right)$ & 71 (0 1) & $7.4\left(\begin{array}{lll}0 & 1\end{array}\right)$ & $7.0(0.04)$ & 0.0001 \\
\hline
\end{tabular}

有意差検定 : Mantel-Haentzel $\chi^{2}$ 検定

作業時間・睡眠時間の数字は平均値 (標準誤差)

性別有意差 : ${ }^{* *} \mathrm{p}<0.001,{ }^{* *} \mathrm{p}<0.01,{ }^{*} \mathrm{p}<0.05$ 年齡階層別有意差 : p-value

$63.4 \%$ ，女性70 .4\%) が男女共通して多かっ た。加えて, 男性では農薬散布 (68.6\%), 女 性ではマルチング作業 (60 2\%) が多かった。

男女差がみられた作業のうち男性の方が多く 実施している作業は，溝上げ (男性47 .0\% , 女 性36 3\%,p $<0.001$ )，農薬散布（男性68.6\%， 女性39 8\%, p <0.001)，ジベレリン処理（男 性56 5\%, 女性31 3\%, p < 0 .001) の3種 類 だった。女性の方が多く実施している作業は， 葉かき(女性84 5\%, 男性73.0\%，p<0.001)， ランナー取り（女性90.7\%，男性85 .0\%, p <
0.01 )，マルチング作業（女性60 2\%，男性 $48.5 \%, \mathrm{p}<0.001$ ), 選別・調整作業（女性 $70.4 \%$ ，男性63.4\%，p<0.05)，八ウスビ ニール張り作業（女性59 3\%，男性50.4\%,p <0.01) だった。一方, 男女差がみられなかっ た作業は, 収穫作業, サイドのビニール張り作 業, 天井ビニールを張るための下準備だった。

年齢階層で差がみられた作業の中で, 高年齢 層ほど多く実施している作業は，男性では葉か き $(\mathrm{p}<0.001)$, ランナー取り $(\mathrm{p}<0.001)$, マルチング作業 $(p<0$.05) , サイドのビニー 
ル張り作業 $(p<0.01)$, ハウスビニール張り 作業（ $\mathrm{p}<0$.01）だった。女性では農薬散布（p <0.05) のみだった。

いちご栽培にかかわる1日の平均作業時間 は, 男性が8 5時間で, 女性の7 9時間に比べて 長かった $(\mathrm{p}<0.001)$ 。年齢階層別比較では， 男性においてのみ若年齢層ほど作業時間が長 かった $(\mathrm{p}<0.01)$ 。

1 日の平均睡眠時間は, 女性が男性に比べて 短く (男性7 .6時間，女性7 .0時間, $\mathrm{p}<0.001$ )， 男女ともに若い年代ほど短かった $(\mathrm{p}<0.001)$ 。 特に40歳代女性の平均睡眠時間は6.5時間と短 く，6 時間未満の割合が12 1\%と他の年代 (50 歳代5 3\%，60歳代2 2\%) に比べて多かった。
3.主な身体的疲労部位 (目, 肩, 腰) と作業 内容との関連 (表 3 )

目の疲労との関連では，ほとんどすべての作 業内容に有意性を認めた。男女ともにオッズ比 が 2 以上と高かったのは，選別・調整作業 [男 性オッズ比 (以下, OR と略) : $2.7,95 \%$ 信頼 区間 (以下, CI と略) : 1 9 3 8, 女性 OR 2 1; CI1 4 3 2] と, 収穫作業(男性 OR 2.6 ; CI1 8〜3 .7, 女性 OR3 2 ; CI2 .0〜5 1)] だった。男性においてのみオッズ比が高かった 作業は，天井ビニールを張る下準備 (OR2 1； CI1 5〜2 9) , ハウスビニール張り作業 (OR 2 .0; CI1 5〜2 8), ジベレリン処理 (OR2 1 ; CI1 5〜2 8) の3作業だった。女性でオッ ズ比が高かった作業は, ランナー取り(OR

表 3 .身体的疲労部位と関連作業要因のオッズ比 ${ }^{\#}$ (95\%信頼区間)

\begin{tabular}{|c|c|c|c|c|c|}
\hline \multirow{2}{*}{ 関連作業要因 } & \multirow{2}{*}{ カテゴリー } & \multirow{2}{*}{ 性別 } & \multicolumn{3}{|c|}{ 身体的疲労部位 } \\
\hline & & & 目 & 肩 & 腰 \\
\hline \multirow[t]{2}{*}{ 溝上げ } & しない/する & 男性 & $2.0(1.4 \sim 2.7)^{* * *}$ & $13(09 \sim 18)$ & $1.7(12 \sim 24)^{* *}$ \\
\hline & & 女性 & $1.6(11 \sim 2.3)^{*}$ & $12(08 \sim 18)$ & $11(0.7 \sim 1.7)$ \\
\hline \multirow[t]{2}{*}{ 葉かき } & しない/する & 男性 & $14(1.0 \sim 19)$ & $15(11 \sim 22)^{*}$ & $11(0.7 \sim 1.6)$ \\
\hline & & 女性 & $2 \sim 3.6)^{* *}$ & $9 \sim 2.6)$ & $0.7 \sim$ \\
\hline \multirow{2}{*}{ ランナー取り } & しない/する & 男性 & $12(08 \sim 19)$ & $13(08 \sim 2.0)$ & $14(0.9 \sim 22)$ \\
\hline & & 女性 & $3.0(1.4 \sim 62)^{* *}$ & $1.6(08 \sim 3.0)$ & $18(0.9 \sim 3.5)$ \\
\hline \multirow[t]{2}{*}{ 農薬散布 } & しない/する & 男性 & $15(11 \sim 21)^{*}$ & $15(11 \sim 2.0)^{*}$ & $2.0(14 \sim 28)^{* * *}$ \\
\hline & & 女性 & $1.5(1.0 \sim 2.3)^{*}$ & $1 \sim 2.4)^{*}$ & $13(0.9 \sim 21)$ \\
\hline \multirow[t]{2}{*}{ ジベレリン処理 } & しない/する & 男性 & $21(15 \sim 28)^{* * *}$ & $11(08 \sim 16)$ & $1.7(12 \sim 24)^{* *}$ \\
\hline & & 女性 & $1.7(11 \sim 2.6)^{* *}$ & $1.4(0.9 \sim 21)$ & $0.9(0.6 \sim 1.4)$ \\
\hline \multirow[t]{2}{*}{ マルチング作業 } & しない/する & 男性 & $19(14 \sim 26)^{* * *}$ & $1.4(1.0 \sim 1.9)^{*}$ & $15(1.0 \sim 21)^{*}$ \\
\hline & & 女性 & $1.7(11 \sim 2.5)^{* *}$ & $13(08 \sim 19)$ & $0.9(0.6 \sim 13)$ \\
\hline \multirow{2}{*}{$\begin{array}{l}\text { サイドのビニー } \\
\text { ル張り作業 }\end{array}$} & しない/する & 男性 & $1.6(11 \sim 21)^{* *}$ & $14(11 \sim 19)^{*}$ & $1.7(12 \sim 24)^{* *}$ \\
\hline & & 女性 & $1.5(0.9 \sim 21)$ & $1.4(0.9 \sim 21)$ & $08(0.5 \sim 12)$ \\
\hline \multirow{2}{*}{$\begin{array}{l}\text { 天井ビニール } \\
\text { を張る下準備 }\end{array}$} & しない/する & 男性 & $21(15 \sim 2.9)^{* * *}$ & $13(0.9 \sim 18)$ & $1.5(11 \sim 21)^{*}$ \\
\hline & & 女性 & $18(12 \sim 2.7)^{* *}$ & $13(08 \sim 18)$ & $08(0.5 \sim 12)$ \\
\hline \multirow{2}{*}{$\begin{array}{l}\text { ハウスビニール } \\
\text { 張り作業 }\end{array}$} & しない/する & 男性 & $2.0(15 \sim 28)^{* * *}$ & $1.5(11 \sim 2.0)^{*}$ & $1.7(12 \sim 2.4)^{* *}$ \\
\hline & & 女性 & $1.6(11 \sim 2.3)^{*}$ & $1.5(1.0 \sim 22)^{*}$ & $08(0.5 \sim 13)$ \\
\hline \multirow[t]{2}{*}{ 収穫 } & しない/する & 男性 & $2.6(18 \sim 3.7)^{* * *}$ & $14(1.0 \sim 2.0)^{*}$ & $1.6(11 \sim 2.4)^{* *}$ \\
\hline & & 女性 & $32(2.0 \sim 51)^{* * *}$ & $14(0.9 \sim 23)$ & $12(08 \sim 2.0)$ \\
\hline \multirow[t]{2}{*}{ 選別・調整 } & しない/する & 男性 & $2.7(1.9 \sim 38)^{* * *}$ & $12(0.9 \sim 16)$ & $1.5(1.0 \sim 21)^{*}$ \\
\hline & & 女性 & $21(14 \sim 32)^{* * *}$ & $13(0.9 \sim 2.0)$ & $12(0.7 \sim 1.9)$ \\
\hline
\end{tabular}

${ }^{\#}:$ 年齢，作業時間，及び睡眠時間による補正を行なつた $* * * \mathrm{p}<0.001,{ }^{* *} \mathrm{p}<0.01,{ }^{*} \mathrm{p}<0.05$ 
3.0 ; CI1 4〜6 2) と葉かき(OR2 1; CI1 2 〜3.6) の 2 作業だった。

肩の疲労との関連で男女ともに有意差を認め た作業内容は, 農薬散布 (男性 OR1 5; CI1 1 〜2 .0, 女性 OR1 .6; CI1 1〜2 4) とハウスビ ニール張り作業（男性 OR1 .5; CI1 1〜2.0， 女性 OR1 5 ; CI : 1 .0〜2 2) だった。

腰の疲労との関連では, 男性は 9 項目の作業 (葉かき，ランナー取りを除く) で有意差を認 め, 中でも関連が強かったのは農薬散布( OR 2 .0 ; CI1 4〜2 8) だった。女性では有意差を 認めず, 最も高いオッズ比を示したのはラン ナー取り (OR1 8; CIO 9〜3 5) だった。

$$
\text { IV. 考察 }
$$

\section{1. 結果の妥当性}

結果を解釈するにあたっては，いちこ栽培従 事者の集団を対象にした断面調査であることに よるバイアスを考慮する必要がある。すなわ ち, 要因と健康影響の関連についての結果で は，これらを同時点で調査していることを考慮 する必要がある。作業要因と自覚疲労症状のど ちらが先行していたかは不明である。両者に関 連を認めても, 兴の要因が症状のリスク要因で あると直ちに結論することはできない。もし， 症状があるために予防的行動がとられているな らば，本来みられる関連が弱まったり，関連の 方向が逆になったりする可能性があるからであ る。

\section{2 . 主な身体的疲労部位と頻度}

立ち作業が中心となる半導体製造事業所にお ける腰痛経験者は40歳以上の男性が56 .9\%, 女 性では56 .0\%との報告がある ${ }^{9)}$ 。厚生労働省の 労働者健康状況調査 (平成14年) に上る腰痛経 験者は, 男性では40歳代30 8\%，50歳代30 8\%， 60歳以上27 3\% , 女性では40歳代32.0\%，50歳 代34 2\%，60歳以上36 5\%となっている ${ }^{10)} 。$ れらの結果と比較すると，いちこ栽培従事者の 腰の疲労症状（男性74 .0\%，女性73 8\%) は， かなり高いと言える。

1986年に福岡県のいちこ栽培従事者 (平均年

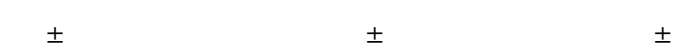

9 1歳) を対象とした本調査と同樣の質問紙法 による自覚疲労調査が行なわれている11)。

当時の自覚疲労症状の愁訴率は, 腰（男性 58 1\%，女性82 5\%)，肩（男性51 2\%，女性 $64.9 \%$ )，目（男性39.5\%，女性70 2\%）と報 告されている。これに対して，本研究における いちこ栽培従事者 (平均年齢士 標準偏差 : 男性

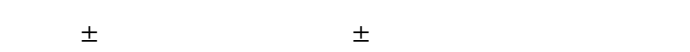
部位は, 腰 (男性74.0\% ,女性73.8\%)，肩(男 性49.6\%, 女性60.4\%), 目（男性45 2\%, 女 性50 .9\%) だった。この約20年前の自覚疲労症 状と比較すると, 平均年齡が約10歳高くなって いるにも関わらず, 女性の目の疲労が低下して いる。弚の理由としては, 照明や作業台の工夫 等の環境面を改善してきたことによる効果が考 えられる。一方で, 男性の腰の愁訴率が高く なっている。腰痛の増悪因子としては，いちご 栽培の作業姿勢の主体が依然として前屈姿勢で あること, 栽培作業による腰部への負担の蓄 積，加齢による筋力低下か推測される。加えて 機械化の導入に伴う腰部機能の低下の影響も少 なくないと考えられる ${ }^{12)}$ 。前屈姿勢がワークサ イクルの $10 \%$ 以上を占めると, 浅い前屈であれ 深い前屈であれ, 腰痛発生のリスクを高めると 述べられており ${ }^{13)}$, 前屈姿勢が30\%を超える場 合には，できるだけ早急に改善を要するとする 報告がある ${ }^{14)}$ 。

\section{3 . 腰の疲労と作業要因}

職業に関連した腰痛は, 多樣な要因と午の組 み合わせにより引き起こされる。「職場におけ る腰痛予防対策指針」では, 腰痛の発生要因と して(1)動作要因 (動的あるいは静的に加わる腰 部への負担)，(2)環境要因（照明，作業面，狭 (作業場など)，(3)個人的要因（年齢，性，生 活習慣，既往歴等) の3 点に大きく分類されて (る ${ }^{15)}$ 。動作要因における動的負担とは筋収縮 の繰り返しによるもので, 筋ポンプ作用により 血液循環を促進し，筋肉・関節・腱に過負荷を 生じた状態である。一方，静的負担とは，座 位，立位，膝たて，中腰姿勢等の持続により血 管を圧迫し，末梢循環の妨害から筋疲労を容易 に生じさせる状態である。 
いちご栽培では前屈姿勢での作業内容 (葉か き, ランナー取り, ジベレリン処理, 収穫作 業, 選別・選別作業等) が多く, 動作要因とし て, 前屈姿勢保持による腰背部への静的負担 に, 運搬作業 (農薬散布, ビニール張り作業な ど）の動的負担が加わり, 腰部への負荷の程度 が大きくなっていると考えられる。

環境要因について今までの報告をみると副， 選別・調整作業を行なう作業場の照明，作業 面, 狭い作業場が, 腰痛の発生要因として重要 であることが指摘されている。

個人的要因としての年齢・性による明確な差 は, 腰痛の愁訴率ではみられなかった。しか し, 腰痛と作業要因との関連では, 男性では 9 項目の関連作業に有意性がみられたのに対し， 女性ではどの作業においても有意性は認めな かった。この腰痛と作業要因との関連における 性差については今後追求すべき課題である。

\section{4 . 肩の疲労と作業要因}

重量物を手に持って運搬したり，長時間同じ 姿勢を続けたりしていると僧帽筋・肩甲挙筋・ 菱形筋が緊張したままになり, 血液の循環が悪 化することが, 肩の疲労の主な原因と考えられ る。

厚生労働省の労働者健康状況調査では ${ }^{10)}$, 肩・腕・手の疲労の愁訴率が男性 : 40歳代16.9 ２1 .4\%，50歳代23 .0〜26 8\%，60歳以上24.4 ３2.6\%, 女性：40歳代28 5〜36.5\%，50歳代 24 2〜34 8\%，60歳以上14.7〜17 2\% と報告さ れている。これらと比較すると，いちこ栽培従 事者の愁訴率 (男性：40歳代54 2\%，50歳代 51 5\%，60歳代42 .9\%，女性：40歳代60 .5\%， 50歳代60 8\%，60歳代59 9\%) が，かなり高い ことがわかる。作業内容との関連では, 肩の疲 労は農薬散布と関連が強かった。農薬散布では 散布器具を肩にかけて作業を行なうため, 肩へ の負担が大きい。男性より女性で関連が強かっ たのは, 女性の筋量が男性に比べて少ないこと が要因のひとつと考えられる。

肩の疲労はハウスビニール張り作業とも関連 が強かった。ハウスビニール (農業用保温被覆 材) の重量は, 軽いものでも単位面積 (1平方
メートル) あたり100g〜120g である。

このハウスビニール張り作業では, 重いビ ニールを抱えたり，運搬したり，支えたりする 作業が多いため，肩への負担が非常に大きくな る。

5 . 目の疲労と作業要因

目を酷使することで，休憩をとっても目の疲 れが残る眼精疲労を起こす。症状としては, 目 が疲れるほかに, 視力低下, 目の痛み, 充血, かすみ目，ドライアイなどがある。主な原因に は, 目の調節機能の低下があり，高齢化によっ て目の調節機能が減衰する場合，あるいは近く のものを長時間見続けて作業する場合にも目の 調節機能は低下する。目以外の身体上の原因と しては, 睡眠不足, 慢性的な疲労, 過労, ス卜 レス等が考えられる。さらに作業環境が悪い場 合，例えば室内の照明が弱すぎたり強すぎたり する場合も原因となる

本調査では目の疲労は収穫と選別・調整作業 が男女ともに強い関連があった。従来から言わ れている通り，いちごは傷みやすいばかりでな く, 色の着色具合をみながら収穫し, 形や品質 別に選別・調整作業をしなければならず，こと のほか神経を集中させる必要がある。また，い ちごの赤い色が目の疲労を増している可能性も ある ${ }^{18}$ 19)。

厚生労働省の労働者健康状況調査では ${ }^{10)}$, 目 の疲労の愁訴率が男性 : 40歳代40 2〜48 8\%， 50歳代47 2～50 2\%，60歳以上25 4 41 4\%， 女性：40歳代44 3〜 44.7\%，50歳代31.0〜 $462 \% ， 60$ 歳以上24 2〜24 5\% と報告されてい る。いちご栽培従事者の愁訴率の方が，女性の 50〜60歳代で高い傾向がうかがえる。光の理由 は，ランナー取りと葉かき作業が女性の目の疲 労とのみ関連が強かったことから，女性はラン ナー取りと葉かき作業でも収穫や選別・調整作 業と同樣に神経を集中させているため，と考え られた。

6 . 腰痛を予防するための工夫

腰痛はいちこ栽培従事者にとって最も愁訴率 が高い疲労であり，いちこ栽培と切り離せない 障害である。腰痛を予防するためには，いちご 
栽培作業の動作要因に最大限の注意を払い, 慢 性化を防ぐための方策をとる必要がある。

最も大切な注意点は，「腰の安定」である。 具体的な例としては，いちごの入ったケース等 を持ち上げる場合，ヶースのほうに近づくか， ケースを自分の方に引き寄せ，しゃがむか㬵を ついた姿勢をとってから物を持ち上げる。重い 物を動かすときは，引くより押す方が腰は安定 するので，膝を曲げ，肘を身体につけて押す。 また , ハウスビニール張り作業等で頭上に手を 伸ばすときは, 足台か脚立を用いる。腰を捻ら ないようにすることが大切であり，身体の向き を変えるときは, まず足から方向を変え, 腰は 最後にする。低い位置にある物を取ったり，動 かしたりするような場合には，しゃがんで行 なった方が腰は安定する。

同じ姿勢を続ける場合は, 頻繁に姿勢を変え ることが大切になる。椅子に腰掛けている場合 には，できるならば，片足ずつ膝を胸に引き寄 せて背中の筋肉を伸ばすとよい。

選別・調整作業室やビニールハウスなどのす べてのドア，引き出し，空の滑りをよくするこ とも重要となる。開かないドアは,できるだけ 引くのではなく，押す力で開けるように気をつ けるべきである。床や階段には，滑ったりつま ずいたりしやすいものを置かない。荷物を運ぶ ときは, 車のついた道具を利用して運ふらよう心 がけたい。また，積みすぎて腰に負担をかけな いように, 重いものは何度かに分けて, 軽くし てから運ぶようする。

溝上げ等で溝を掘るときは，あらかじめ土を 湿らせて柔らかくしておく。ただし, 水分を含 みすぎて重くならない程度にする。用具はよく 切れるもの，よく掘れるものを使う。手入れを して, 用具の可動個所がすべて滑らかに動くよ うにしておく必要がある。

葉かき，ランナー取りでは一般的には作業台 車に腰掛けて作業が行なわれているが，もし， 膝をつかなければならない場合には, 足, 足 首, 膝の関節の衝撃吸収機能がうまく働かない ので, 腕にかかるカが直接背中や腰に伝わって しまう。このような場合は, 片膝をつき, 片手
を地面につけると，身体をさらに安定させるこ とができる。

高設栽培では立ち作業が多くなるが, 足の疲 れが腰に負担をかけることがあるので, 足にも 適切な配慮が欠かせない。靴は衝撃を吸収して くれるものがよい。かかとや靴底のクッショ ン，中足骨部のパッド，土踏まずの支え，厚め の靴下などで, 安定性や衝撃吸収性を高めるこ とができる。

収穫や選別・調整作業では, 窮屈な姿勢を余 儀なくされる。椅子を使う場合は，椅子に融通 性を持たせ，作業面の高さを調整するととも に, 頻繁に姿勢を変えて同じ姿勢を長く続けな い工夫をする。

腰痛の既往歷がある場合には腹筋と背筋の低 下か認められることから，これらの筋肉をスト レッチして過緊張を防ぎ, 筋肉への負担をでき るだけ軽くすることも工夫のポイントになる。 さらに, 疲労を起こしにくくするために, 腹 筋, 背筋, 大臀筋，大腿筋などの筋肉を日頃か ら鍛えるような自己管理も大切となる。

\section{7 . 肩の疲労を予防する工夫}

肩こりなどで代表される有痛性痙縮による筋 肉の痛みを経験することがある。血流量減少に よって筋肉内の酸素欠乏状態が出現すると, 筋 肉疲労か現れ，疲労物質か蓄積することで疼痛 が生じるからであり，疲労が回復せず，筋肉の 機能を十分果たせなくなる。このような筋肉疲 労に対しては, 筋肉のストレッチが心臓に戻る 静脈の血液の流れを助ける。したがって, 農薬 散布やビニール張り作業のような重量物の運搬 を継続しなければならない場合は，作業の合間 に，僧帽筋・肩甲挙筋・菱形筋に対するス卜 レッチを取り入れ，これらの筋肉の柔軟性保持 と血液循環の悪化防止が大切となる。

\section{8 . 目の疲労を予防する工夫}

いちこ栽培作業では, 収穫, 選別・調整作業 により調節性眼精疲労 (同じ距離のものを見続 けると常にピントを合わせる努力が必要なた め, 水晶体の厚さを調整する毛样体筋か波労す る) や神経性眼精疲労 (長時間の目の酷使に よって生じることが多く, 精神的な緊張が続い 
ても生じる）を起こし，血液の循環が悪化する と考えられる。したがって, 収穫, 選別・調整 作業, あるいはランナー取りや葉かき作業等を 行なう場合は, 1 時間に 1 回程度は目を休ませ るために遠くを見たり，目を閉じたりする工夫 が必要となる。目頭, 目じり, こめかみなどの マッサージや指圧, 眼球体操（目を閉じたまま 眼球を上下左右にゆっくり動かすなど）も疲労 の軽減や予防に効果的である。温かいタオルを 目に乗せることも, 目の血行促進に役立つ。

$$
\mathrm{V} \text {. 結 論 }
$$

福岡県内における中高年のいちご栽培従事者 (40〜69歳) を対象に, 自記式調査票を用い て, 主な身体的疲労部位と作業内容との関連に ついて検討した。

いちご栽培作業による身体的疲労部位の訴え が高かったのは, 腰 (男性74 .0\%，女性73 8\%)， 肩（男性49.6\%，女性60.4\%），及び，目（男性 $452 \%$ ，女性50 9\%) だった。これらの疲労部 位と最も強い関連があった作業は, 腰では, 男 性は農薬散布（OR2 .0；CI1 4〜2 8) だった が, 女性では有意な関連はみられなかった。肩 では, 男性は葉かき作業 (OR1 5; CI1 1〜 2 2), 女性は農薬散布（女性 OR1 .6 ; CI1 1〜 2 4) だった。目の疲労では, 男性は選別・調 整作業 (OR2 .7; CI1 9〜3 8), 女性は収穫作 業 (OR3 2 ; CI2 .0〜5 1) だった。

いちごの品種改良や新しい栽培方法などの労 働態樣の変化, 並びにいちご栽培従事者の高齢 化が進行中の現在においても, 身体的疲労部位 は腰・肩・目に多かった。疲労対策では, 強い 関連を認めた作業内容, 及び性差を考慮する必 要性があると考えられた。

$$
\text { 謝辞 }
$$

稿を終えるにあたり，本調査にご協力いただいた JA 全農ふくれん園芸部各位, 並びにJA 福岡中央会経営局 各位に深甚なる謝意を表します。

$$
\text { 文献 }
$$

1 ) 九州農政局福岡農政事業部. 農作物の部 (野菜) : 福岡県の農業データ，2002, 48-53。
2 ) 農林水産省大臣官房統計部 . 平成15年農業構造動 態統計調査報告：農家の人口及び学働 (福岡県) . 東京: 農林統計協会, 2004 .

3 ) 松尾孝則, 大串和義, 田中龍臣 . 促成イチゴの省 力的育苗技術の開発.九州農業研究 1994; 56 : 194 .

4 ) 田中修作, 西本 太, 守屋勝行, 他 . イチゴ高設 栽培技術の確立. 九州農業研究 $2000 ; 62: 180$.

5 ) 松尾孝則, 田中龍臣 . 促成イチゴの夏期低温短日 処理育苗による前進出荷栽培. 九州農業研究 $1990 ; 52: 187$.

6 ) 関 正裕, 西田初生, 高橋仁康 . イチゴ作業の作 業負担調査. 九州農業研究 $1999 ; 61: 151$.

7 ) 北山孝子, 石田順子，木之下幸子，他 . 農業従事 者の快適な作業場の条件設定について，鹿児島農 医研誌 $1999 ; 29: 56-57$.

8 ) 高尾雅晴, 黑川幸彦.いちごの産地間競争と産地 組織の機能.九州農業研究 $1992 ; 54: 188$.

9 ) 小宮康裕.職場の体力・健康づくりの展開と効果. 日本産業衛生学会・労衝者体力問題研究会編 . 神 奈川: 財)労働科学研究所出版部, 2001.

10）厚生労働省大臣官房統計情報部 . 企業における健 康づくりの展開と効果 . 東京 : 労務行政, 2002 .

11）末永隆次郎, 前田勝義, 山田統子, 他 .いちこ栽 培者における腰部負担の解析 . 日農医誌 1986 ; 35(2) : 134-146.

12）末永隆次郎, 林田勝子, 木原裕子, 他. 施設園芸 栽培従事者の体格・体力について一特に腰部機能 の10年間の推移一.九州農医誌 $1995 ; 4: 13$ 14 .

13) Keyserling WM, Punnet L, Fine LJ. Trunk posture and back pain : Identification and control of occupational risk factors. Applind Industrial Hygiene. $1988 ; 2: 87-92$.

14) Veikko L, Timo S. OWAS : a method for the evaluation of postural load during work. Helsinki Institute of Occupational Health. 1992.

15) 厚生労働省労働基準局安全衛生部労働衛生課.職 場における腰痛予防対策指針. 季刊労衝衛生管理 $1994 ; 5: 34-59$.

16) 末永隆次郎。農業生産条件の変化と労働負担 .日 農医誌 $1996 ; 45(3): 186-187$.

17) 渥美一成. 調節・眼精疲労コンパクト眼科学(16). 東京: 金原出版, 1999 .

18) Jacobs KW, Blandino SE. Effects of color of paper on which the profile of mood states is printed on the psychological states it measures. Perceptual and Motor Skills. $1992 ; 75$ (1) : 267-271.

19）金子隆芳.色の科学一光の心理と生理と物理. 東 京 : 朝倉書店, 1995 . 


\title{
Prevalence of Physiological Fatigue and Risk Factors Among Middle-Aged Strawberry Growers
}

\author{
Yoshito MOMOSE ${ }^{*}$, Takajiro SUENAGA ${ }^{2 *}$ and Hiroshi UNE*
}

OBJECTIVES : With the spread of new cultivation methods of strawberries, working conditions have been changed in recent years. Strawberry growers have also been advanced in age. And now, the need to take new measures against physiological fatigue in strawberry growers has become pressing. We investigated the relationship between physiological fatigue and risk factors among middle-aged strawberry growers due to a paucity of such epidemiological studies. DESIGN : Cross-sectional study. Questionnaires were mailed to strawberry growers. SETTING : A rural district in southern part of Japan. SUBJECTS : A total of 1,113 healthy strawberry growers (681 men and 432 women) who were 40 69 years of age. RESULTS : Prevalence of low back pain was the highest (74.0\% of males and $73.8 \%$ of females), followed by shoulder stiffness and/or pain (49.6\% of males and $60.4 \%$ of females), and eyestrain $(45.2 \%$ of males and $50.9 \%$ of females). After adjustment of age, working hours, and sleeping hours using a logistic regression analysis, low back pain had the strongest association with agriculturalchemicals spraying among males (odds ratio 2.0 ; 95\% confidence interval 1.4 to 2.8), but there was no significantly association among females. Shoulder stiffness and/or pain had the strongest association with removing old leaves among males (odds ratio $1.5 ; 95 \%$ confidence interval 1.1 to 2.2 ), and with agricultural-chemicals spraying among females (odds ratio $1.6 ; 95 \%$ confidence interval 1.1 to 2.4 ). Eyestrain had the strongest association with strawberry sorting among males (odds ratio $2.7 ; 95 \%$ confidence interval 1.9 to 3.8 ) and with strawberry harvesting among females (odds ratio 3.2 ; 95\% confidence interval 2.0 to 5.1 ). CONCLUSON : Although the main physiological fatigue among males and females were similar in prevalence, related risk factors differed, and thus the results suggest that it is necessary to take measures against physiological fatigue in consideration of sex difference in the case of middled-aged strawberry growers.

\footnotetext{
* Dept. of Hygiene and Preventive Medicine, School of Medicine, Fukuoka University, Fukuoka, Japan

${ }^{2 *}$ Dept. of Environmental Medicine, School of Medicine, Kurume University
} 